\title{
Classical Javanese Manuscripts Contribution for Educational Tourism Destination
}

\author{
R Adi Deswijaya ${ }^{1}$, Agus Efendi ${ }^{2}$ \\ \{1 adides2016@gmail.com, ${ }^{2}$ kambang.leng@yahoo.co.id\} \\ ${ }^{12}$ Universitas Bangun Nusantara, Indonesia
}

\begin{abstract}
Tourism has become one of Indonesian main priority sectors to support national economic income. Tourism aims at not only for recreation and self-development but also for education process. Educational tourist destinations are needed here. The qualitative research method is one of the steps used to address the problems in this study. Less information about certain educational tourist destination contributes to some obstacles exist in developing the tourism sectors esspeacially the educational tourism. The study uses a qualitative method. The research data is the form of words, phrases and sentences related to the historical story information of a place, building or object. The data source is the carik script titled Pratelan Wontenipun Candhi, Reca, Patilasan, Padusan sasaminipun, ing Bawah Kitha Surakarta. Classical Javanese manuscripts is written documents that can be used to solve this problem. Classical Javanese manuscripts about journey (Journal Classical Javanese manuscripts) can give additional information about the history of certain tourism resorts. Nowadays, tourist destination is not only for enjoyment but also for education. The novelty of this research is to focus on more extracting historical information on the existence of a place or building or still hidden tourist object that is sourced from the text of the Javanese script.
\end{abstract}

Keywords: tourism, educational destination, tourist destination, and classical Javanese manuscript.

\section{Introduction}

Indonesia is famous for it's natural beauty and cultural diversity. Each island in Indonesia has it's own cultural richness such as temple, palaces, traditional house, traditional costume, traditional ceremony, and folklore. These all can be tourist destination as well. Even, they can compete to the natural tourist destination such as beach, mountain, lake, etc. Those natural beauty and cultural diversity can be managed to be tourist destinations to increase the national and local economic income.

Tourism is one of Indonesian main priority sectors to support national economic income. The offering of new tourism destination in Indonesia and its tour package through online application such as website, Instagram, facebook, and so on is an interesting way to promote the tourism potency of certain place. This can be a beneficial thing for the development of tourism in Indonesia. Even, some tourists in this millennial era visits some tourist destination 
is just for taking selfie pictures then upload them in to their social media. They do not pay attention much on the history and the knowledge about the tourism destination they visit. However, some tourists have serious attention on the importance of learning about the history of tourism destination. They exploit their visiting for enjoyment as well as education. It is known as educational tourism.

There are still many tourist destinations that have not exposed yet. To do so, it is necessary to embrace the local society to take a part in developing and promoting their regional tourism potential especially those dealing with educational tourism that is based on the local wisdom. Adiyosi in Dewi et al confirms that society participation is the most important element in the growth of independence and the process of empowerment[1].

Unfortunately, most of tourism natural resources and cultural diversity is just a dumb witness since there is not enough information especially that of dealing with their history. Dealing with educational tourism, such kind of information like the history about the tourism resort is very useful for the learning of the tourists. The Lack or even not available of reliable information makes obstacles in the field of tourism so far to develop tourist destinations, both already exposed and still hidden.

The research of the development tourist destinations was discussed in many previous studies, but not yet found any research that concerns about the importance of extracting information about the history of the existence or occurrence of tourist objects that already exist or still hidden. The discussion of previous studies are more directed to (1) the role of local communities in the development of tourist attraction; (2) The forms of tourist destinations can be developed; and (3) The attraction of Tourist attractions. Based on previous research, this research focuses on morestrategies to present historical information on the existence or occurrence of a tourist attraction, both exposed and still hidden as a form of the development educational tourism destinations.

\section{Research Method}

The qualitative research method is one of the steps used to address the problems in this study. According to Strauss and Corbin in Farida said that qualitative research is research that can be used to examine community life, history, behavior, organizational functionalization, social movements, or kinship relations[2].

This research data in the form of words, phrases and sentences relating to the historical story information of the existence of a place, building and objects, such as temples, statues, caves, wells, spring, mosque, and tombs. The large number of classical Javanese script texts that contain stories about the history of the existence of a place or building, making the source of this research data conical in one carik (Javanese Classical script text) carik (handwritten), namely the Pratelan Wontenipun Candhi, Reca, Patilasan, Padusan sasaminipun, ing Bawah Kitha Surakarta Regency 'Information on the existence of temples, statues, petilasan, baths and so on under the city of Surakarta', compiled by Raden Tumenggung Mangunnagara in 1929.

In addition to the text, another source of data used is the informant. The results of interviews with informants are used as a crosscheck of the contents of the text with the reality in the field. Interviews as a form of direct observation of the field were obtained from informants including village elders, heads of households, mosque takmir, local residents, and cultural figures [3]. 
The combination of the contents of the text with the results of the interview will obtain useful data for the addition of information on existing tourist destinations and extracting information that is still hidden. Reduction, data presentation, verification, and data triangulation that refer to the rules of qualitative methods are used as a form of analysis[4].

\section{Results And Discussion}

Tourism Act No. 10 of 2009 in Hariyanto explains that tourism is a travel activity carried out by a person or group of people visiting a particular place, with the aim of recreation, selfdevelopment, or study the uniqueness of tourist attractions that are visited in a temporary period[5]. Related to educational tourism or educational tourism, the explanation of the Tourism Act is very clear that the purpose of tourism is not only as a place for recreation and self-development, but also as a learning process for the uniqueness of the tourist destinations visited by tourists. Hary Hermawan and colleagues emphasized that the educational process carried out in tourism activities is an active and creative learning method, and is an effective alternative learning method[4].

Information about the historical background of the occurrence or existence of a place or object and its function, of course, is needed for the recipient of the learning. Understanding education itself according to KBBI is education[6]. Erlangga added that tourist attractions that have educational value are vehicles that are able to add new knowledge[4]. The lack of written or verbal data sources about background information on the occurrence or existence of a place, building, customs, culture, and other tourist destination objects offered, is a separate note for the local government or the manager of the tourist destination to immediately improve it self. Without this information, it can be said that the tourist attraction is merely a spectacle, not guidance. The information relating to the history of the existence of a place, building, objects, customs, and culture can be extracted through oral and written story products. Spoken or oral products, it is feared to experience a change in the majority of the originality of the story from the first appearance to the process of community acceptance in the present era. It is different with the written story contained in the text, can anticipate the erosion of the storyline since the emergence of the text until the acceptance of the community at the present time.

Text according to KBBI has the meaning (1) text is original words from the author; (2) quotes from the scriptures for the teaching base or reason; (3) written material for the basis of giving lessons, giving speeches, and so on[6]. In the field of Philology, Karsono explain the meaning of text is the content of manuscripts expressed in language or other signs according to the type of discourse[7]. The definition of the script itself according to Dwi Sulistyorini is a form of writing that contains ideas or concepts in the form of material, whether in the form of paper, dluwang, books or the others[8]. Dwi added that in the manuscript containing the teachings of life, moral teachings and local wisdom reflected in the lives of the people who lay behind the story of the manuscript[8]. Based on the opinionsabove it can be made clear that the author's ideas or concepts contained in the text language media represented through several sheets are then collected into one in a case called a manuscript.

Classic has the understanding (1) the highest quality; has a recognized and doubtful position value; (2) ancient Greek and Latin literary, artistic and cultural standards; (3) The characteristic is like classical art, which is simple, harmonious, and not excessive; (4) historic; and (5) traditional (It is about pieces of clothing, art, etc.)[6]. 
Based on the description of the understanding of 'text' and 'classic' above, the classic Javanese script text can be interpreted as the contents of a script or written discourse in Javanese script and language which is very high value. Here, high value has the understanding that the ideas or concepts of writers or authors contained in it about the Javanese civilization of the past that can be used as a benchmark of community life in the present and the future. The definition of classical Javanese script includes printed Javanese text and Javanese carik 'handwritten'.

The source of the written data of the Classical Javanese script text is very beneficial in contributing information related to the history of the occurrence or existence of a place or the results of the cultural community in the past. This information contribution can certainly trigger the growth of new educational tourism destination in the future. However, even though the majority of natural tourist destinations and the cultural products of the local community that have been exposed to social media, the lack of information about the historical background of their existence, as well as for tourist destinations that are still hidden or not yet exposed.

Related to the contents of the text, Pradotokusumo divides text functions consisting of: (1) reference text, (2) expressive text, (3) persuasive text, (4) text about text, (5) social functioning text, and (6) text- literary texts[9]. Pradotokusumo also added that the function of text as a reference is further divided into (1) informative text, (2) discursive text, and (3) instructive text[9]. Based on Pradotoksumo's opinion above, namely about the function of the text as a reference, the Classical Javanese script can be categorized as an informative text. This informative type of text only presents factual news without commenting even though there is no informative text because the selection in terms of facts and the way facts are communicated affects information[9].

Pradotokusumo's description of informative texts is certainly in accordance with the function of Classical Javanese script texts, which can provide information to readers about facts obtained from the author. These facts can be derived from oral information or seen directly by the author. The poured forth of fact is an idea or concept from the author or writer with the aim that the reader is persuaded and then proves what he has been informed.

The text of Javanese script categorized information about the historical background of the existence of a place, objects and cultural products of the local community, for example: (1) Serat Centhini (Pakubuwana V when he was the crown prince of PB IV); (2) Cariyos Purwalelana (Candranagara, 1877); (3) Babad Alit; II. Jumenengipun Cungkup Ing Pasarean Kuthagedhe (Prawirawinarsa/Jayengpranata, 1921); (4) Bocah Mangkunagaran (Yasawidagda, 1937); (5) Cariyosipun Banawi Sala, (Reksakusuma, 1916); (6) Pratelan Wontenipun Candhi, Reca, Patilasan, Padusan sasaminipun, ing Bawah Kabupaten Kitha Surakarta (Raden Tumenggung Mangunnagara, 1929), and so on. Numbers 1 through 5 are stored in Yayasan Sastra Lestari Surakarta (www.sastra.org), while number 6 is stored in the Radya Pustaka Surakarta Museum.

From the six examples of the above text, this study focused on the manuscript text Java script carik handwritten' entitled Pratelan Wontenipun Candhi, Reca, Patilasan, Padusan sasaminipun, ing Bawah Kabupaten Kitha Surakarta, works of Raden Tumenggung Mangunnagara, Bupati Pangreh Praja Kitha Surakarta. The collection of the Radya Pustaka Surakarta Museum was written in 1929. The text of this manuscript or abbreviated PWCRPP, contains information about the existence of temples, statues, petilasan, baths (spring), caves, mosques and so on from as many as 235 villages in the district of Sukoharjo.

After the interview, most of the information contained in this text has not been exposed to the public and a small proportion of information is not shared between the information 
received by the surrounding community and the contents of the text. For example Kewedhusan cave which has not been exposed to the public at all and even by the tourism Tourism Office. Guwa Kewedhusan, according to the story in the text, is a giant hiding place that loses to fight against Jaka Suruh (before becoming Brawijaya I). The cave is also the site of Pakubuwuwana IV's (when he was crown prince) mansion to seek inspiration so he could become king. The cave, which was more or less a few years ago, was still the destination of the caos dhahar of the Surakarta Palace of the Kasunanan family, now it has not been touched at all by the relatives of the palace, so it has not been taken care of by the many rocks covering it and the thick bushes. The surrounding community did not make any effort to preserve historical evidence located on the banks of the Dumpul river, Polokarto, Sukoharjo.
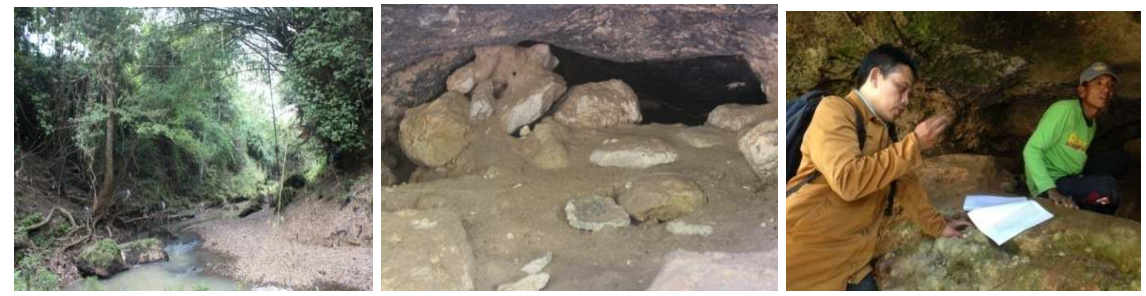

Fig 3.GuwaKewedhusan, Polokarto, Sukoharjo

The other examplesof Guwa Kewedhusan, namely in the form of relics of the mosque in the era of Pakubuwana IV. The mosque named Jatisobo is a relic of the Kyai Ketib Iman, a servant of the palace ketib in KasunananSurakarta. The Jatisobo Mosque, located in the village of Jatisobo, Polokarto, Sukoharjo, has been published by a private television station in Surakarta. This publication is limited to television stations. Sukoharjo Tourism Office has not published it as a religious tourism destination.

Publication by this private station found a mismatch of the story when compared with the contents of the PWCRPP text. Information received by the television station from one of the takmir of the Jatisobo mosque said that the Jatisobo Mosque was a relic of the Pakubuwana IV era (http://youtu.be/C2BqRhX4WFQ), while the contents of the PWCRPP text stated that the Jatisobo mosque was a relic of the Pakubuwana IV era in Surakarta.
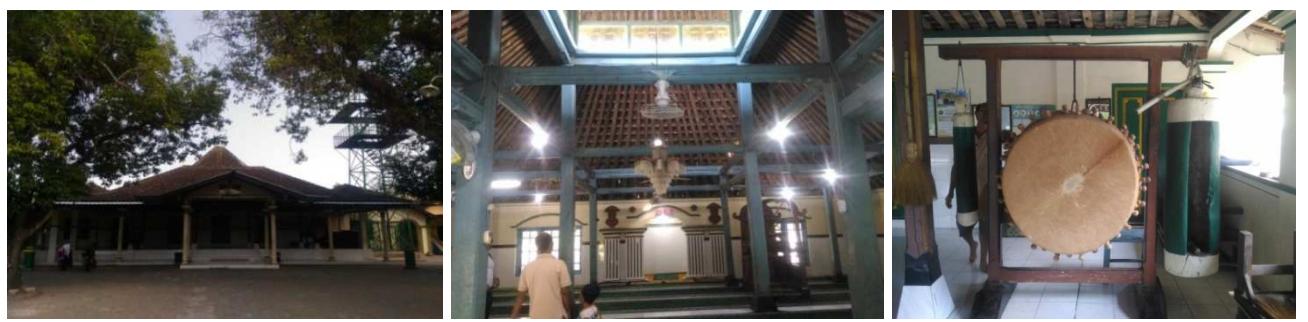

Fig 4. Jatisobo Mosque, Polokarto, Sukoharjo

The two examples of relics in the form of caves and mosques in front are evidence of the importance of the role of classical Javanese script texts in contributing information to the development of the world of tourism, particularly historical, religious, and cultural education tourism destinations that are still hidden.

PWCRPP was composed by RadenTumenggungMangunnagara, a courtier of Bupati Pangreh Praja Kitha Surakarta. A courtier is certainly not rash in compiling or collecting these stories. What he compiled of course on the orders and intended for the king. Like a poet who creates literary works at the behest of his king. The author or writer, through the text of 
the PWCRPP text, tries to re-record the oral stories that exist in the community of Sukoharjo region, such as folklore, local customs and its performances, among others: statues, springs, tombs, caves, mosques, temples, ports, and so on in the form of written documentation. Documenting folklore, local customs and its inspections are not yet known by most local people. Sourced from the documentation in the form of this classic Javanese script, in the future it can be used to track historical, religious, and other cultural products that are still hidden and can then be raised as potential new tourist destinations for educational tourists to visit these places. The role of the local community and local government is certainly very necessary for its development.

This classic Javanese script document can be utilized by the tourism sector in terms of adding information about the historical background of a tourist destination that has developed as well as a means to explore other tourist destinations that are still hidden and deserve to be informed to the public, so as to attract tourists' visits.

The novelty of this research is to focus on more extracting historical information on the existence of a place or building or still hidden tourist object that is sourced from the text of the Javanese script, while the majority of previous studies focus on the handling and development of the attractions that are already available.

\section{Conclusion}

Classical Javanese script text is a written document that can be used as a datasource. The importance of classical Javanese script texts as a written document, can be used as a reference to explore, add and straighten information about the historical background ofa place, building, or objects of past and existing civilization products that are still hidden, so that they are worthy to be appointed by local governments or the local community as a potential new educational tourism destination.

The participation of the regional government or the local community is very much needed in the development of existing tourist destinations and the exploration of prospective new tourist destinations that are still hidden.

Oral word of mouth will always change according to the times, so that the author's goal is to convert oral stories into classical Javanese script to anticipate that the contents of the oral stories used as sources in making the text do not deviate far from the original due to the development era.

\section{References}

[1] M. B. Made Heny Urmila Dewi, Chafid Fandeli, "Pengembangan Desa Wisata Berbasis Paritisipasi Masyarakat Lokal di Desa Wisata Jatiluwih Tabanan, Bali,” Kawistara, vol. 3, no. 2, p. 132, 2013.

[2] F. Nugrahani, Metode Penelitian Kualitatif: dalam Bidang Pendidikan Bahasa. Cakra Books Solo, 2014.

[3] K. Saddhono, "Cultural and social change of foreign students in Indonesia: The influence of Javanese Culture in Teaching Indonesian to Speakers of Other Languages (TISOL)," in IOP Conference Series: Earth and Environmental Science, 2018, vol. 126, no. 1, p. 12091.

[4] F. H. Erlangga Brahmanto, Hary Hermawan, "Strategi Pengembangan Kampung Batu Malakasari sebagai Daya Tarik Wisata Minat Khusus," Media Wisata, vol. 15, no. 2, pp. 592593, 2017. 
[5] O. I. B. Hariyanto, "Destinasi Wisata Budaya Dan Religi Di Cirebon,” Ecodemica, vol. IV, no. 2, p. 216, 2016.

[6] T. P. K. P. Bahasa, Kamus Bahasa Indonesia. Jakarta: Pusat Bahasa Departemen Pendidikan Nasional, 2008.

[7] K. H. Saputra, Pengantar Filologi Jawa. Jakarta: Wedatama Widya Sastra, 2008.

[8] D. Sulistyorini, Filologi Teori dan Penerapannya. Malang: Madani, 2015.

[9] Partini Sardjono Pradotokusumo, Pengkajian Sastra. Jakarta: PT Gramedia Pustaka Utama, 2008. 